\title{
Response of Wet Seeded Rice Varieties to Sowing Dates
}

\author{
Mishri L Shah and Kailash P Bhurer \\ Regional Agriculture Research Station-NARC, Parwanipur-Bara
}

\begin{abstract}
The experiment was conducted at Regional Agriculture Research Station, Parwanipur in two consecutive years to find out the suitable rice varieties for wet seeding conditions in relation to sowing dates. Yield components like tillers number $/ \mathrm{m}^{2}$, number of filled grains $/$ panicle and 1000-grain weight were found in the decreasing trend from the seeding of 15 of June onward. The percent decrease in the grain yield was 14.1,31.8 and 50.6 in 1998/99 where as 4.8, 7.9 and 49.6 in $1999 / 00$ on June 29 to July 14 seeding dates respectively as compared to 15 June seeding date. Radha 4 in the first and Chaite 2 in the second year recorded the highest grain yield of 3757 and $4197 \mathrm{~kg} / \mathrm{ha}$ respectively. Interaction effect of the sowing dates and varieties was highly significant. Radha 4 produced the highest grain yield of $5039 \mathrm{~kg} / \mathrm{ha}$ in 1998/99 where as Radha 4 and Chaite 6 were found at par in 1999/2000 seeded on 15 June. Radha 4 was the best variety for wet seeded conditions when seeded on 15 June. Chaite 2 had been observed good yielder in all seeding dates among the tested varieties.
\end{abstract}

Key words: Grain yield, seeding dates, wet seeding rice

\section{INTRODUCTION}

There are three principal methods of rice establishment; dry seeding consists of sowing dry seeds on dry soil; wet seeding, involves sowing pre-germinated seeds in wet puddled soils; transplanting involves, replanting of rice seedlings grown in nursery to puddled soils. The both dry and wet seeding methods are often referred as direct seeding because the seeds are sown directly. These traditional methods either in irrigated or rainfed ecosystem are labour intensive. Pandey and Velasco (1999) reported that the high labour cost and high requirement of labour for rice transplanting have narrowed the profit margin. Generally water availability and opportunity cost of labor are the major determinants of crop establishment methods. Adequate water supply and low wage rate favor for transplanting. When the water supply is adequate and wage rate is high, the wet seeding is favorable provided the low cost of weed control; thus economy incentives for direct seeding increased under such situation. As a result of rising wage rate the direct seeding method is popular in Southeast Asian countries. The total direct seeded area is about 15 million hectare in Asia only in rainfed lowland and irrigated ecosystem. The importance of direct seeding in irrigated and rainfed lowlands increased during the past three decades mainly in Malaysia, Thailand and Macon Delta (Pandey and Velasco 1999) and continued to expand in South and Southeast Asia where farmers are mostly concerned to lower the cost of rice production through labor saving technology.

It was reported that 23 percent of the total rice growing area in Nepal was under irrigated conditions (Adhikari and Khatiwada 1996/97). Labor scarcity during transplanting period had been realized from many years due to development in the industrial sectors or seasonal migration to Punjab. Mechanization is very costlier as the size of holding is small. Keeping in account the availability of adequate water, high yielding short duration varieties, chemical weed control methods and high wage rate can make a major shift from transplanting to wet seeding. Number of high yielding varieties suitable for transplanting conditions is available, but there was no information on the performance of varieties 
grown under wet seeding conditions. Therefore, efforts had been made to evaluate the performance of rice varieties sown on various dates under wet seeding conditions.

\section{MATERIALS AND METHODS}

The field experiment was carried out at Regional Agriculture Research Station, Parwanipur $\left(27^{0} 04^{\prime}\right.$ latitude and $84^{0} 58^{\prime}$ longitude) at an elevation of 115 masl in two consecutive years (1998/99-1999/00). Four seeding dates at 15 days interval starting from June 15 to July 29 were compared to evaluate the yield potentials of rice varieties Chaite 2, Radha 4, Chaite 6 and Radha 11 under wet seeding conditions. The experiment consisting of two factors (dates and varieties) were laid out in a $4^{2}$ factorial experiment in randomized complete block design, replicated three times. Seeds were soaked in water for 24 hours and incubated for 48 hours; and sown on puddled soil @ $100 \mathrm{~kg} / \mathrm{ha}$ as per treatment in the plot size of 5$\times 2.35-\mathrm{m}$. Net harvest was done in a plot size of 4.5- $\times 1.8-\mathrm{m} . \mathrm{N}: \mathrm{P}: \mathrm{K} @ 40: 40: 30 \mathrm{~kg} / \mathrm{ha}$ were applied as basal and $40 \mathrm{~kg} \mathrm{~N} / \mathrm{ha}$ was top dressed at 30 days after seeding. Butachlor 50 EC @ 2 1/ha was sprayed as pre-emergence to control the weeds. Irrigation was given as per need of the crop for both the years. One hand weeding was done before topdressing. Data were recorded on tillers number $/ \mathrm{m}^{2}$, number of filled grains/panicle, 1000-grain weight and grain yield (kg/ha). Statistical analysis was done using MSTATC.

\section{RESULTS AND DISCUSSION}

\section{Effect of sowing dates on grain yield and yield components}

Results for two years (1998/99-99/00) recorded on yield and yield components are presented in Table 1. Highly significant effect of sowing date was detected on grain yield and yield attributing characteristics like tillers number $/ \mathrm{m}^{2}$, filled grains/panicle and 1000-grain weight in both the years. June 15 seeding had the highest tillers number/m² (240 and 316 in 1998/99-99/00 respectively) whereas the lowest in July 29 seeding. More number of filled grains/panicle was visualized in the early seeding and declined gradually in the successive seeding dates. Early seeding (June 15) had the highest 1000-grain weight and decreased as sowing delayed. June 15 seeding date recorded significantly the highest grain yield in 1998/99 whereas June 15 to July 14 seeding date had statistically the similar yield in 1999/00.

The reason for low yield on July 14 seeding in first year might be due to brown plant hopper infestation. The percent decline in grain yield was 14.1, 31.8 and 50.6 in 1998/99 and 4.8, 7.9 and 49.6 in 1999/00 when seeded on June 29, July 14 and 29 respectively as compared to June 15 seeding. The decreasing trend in the grain yield in delayed seeding might be associated with significantly lower number of

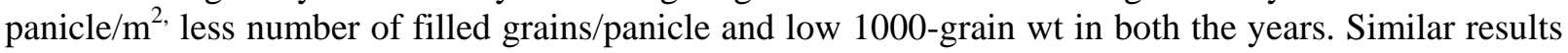
were reported by Koirala (1983), Kunwar and Shrestha (1979) and Bhurer et al (1990). It was also reported that the reason for decline grain yield might be due to delayed panicle formation and grain filling in the season where temperature and solar radiation are less (IRRI 1993). The earlier sown crop benefited from better sunshine and appropriate temperature that resulted into a more vigorous and extensive root system leading to increased vegetative growth means more efficient sink formation and greater sink size, greater carbohydrate translocation from vegetative plant parts to the spikelets and longer leaf area index during grain filling period, thus resulted to high yields in early seeding.

Table 1. Effect of sowing dates on grain yield and yield components

\begin{tabular}{lrrrrrrrr}
\hline Sowing date & \multicolumn{2}{c}{ Tillers/m } & \multicolumn{3}{c}{ Grains/panicle, $\mathrm{n}$} & \multicolumn{1}{c}{ 1000-grain wt g } & \multicolumn{2}{c}{ Grain yield, kg/ha } \\
\cline { 2 - 9 } & $1998 / 99$ & $1999 / 00$ & $1998 / 99$ & $1999 / 00$ & $1998 / 99$ & $1999 / 00$ & $1998 / 99$ & $1999 / 00$ \\
\hline 15 June & 240 & 316 & 100 & 99 & 22.2 & 24.2 & 4357 & 4497
\end{tabular}




\begin{tabular}{lrrrrrrrr} 
29 June & 186 & 277 & 105 & 81 & 21.9 & 23.9 & 3746 & 4282 \\
14 July & 166 & 258 & 92 & 86 & 21.1 & 23.9 & 2972 & 4146 \\
29 July & 169 & 199 & 71 & 65 & 20.7 & 23.7 & 2154 & 2266 \\
\hline CV, \% & 15.4 & 14.3 & 20 & 14.5 & 4.6 & 4.5 & 17.2 & 17 \\
LSD $(0.05)$ & 24.8 & 33 & 15 & 9.8 & 0.82 & - & 476 & 592 \\
\hline
\end{tabular}

Effect of varieties on grain yield and yield components

Chaite 6 gave significantly higher number of tillers $/ \mathrm{m}^{2}$ in both the years, but at par with Radha 4 in 1998/99 (Table 2). Chaite 2 had the highest number of grains/panicle whereas Chaite 6 had the lowest in both years. Radha 4 had the heaviest grains (24.8 and $27.8 \mathrm{~g}$ in 1998/99 and 1999/00 respectively) whereas minimum was noted from Radha 11 in both the years. The differences in the grain yield, obtained in Chaite 2, Radha 4 and Chaite 6 in 1999/00 were insignificant whereas in 1998/99 Chaite 2 and Radha 4 and Radha 11 had the same yield. Chaite 2 yielded the highest grain of $4197 \mathrm{~kg}$ in 1999/00 whereas in 1998/99 Radha 4 had the highest (3757 kg/ha). Radha 11 was the lowest yielder in both the years among the tested varieties. This was mainly influenced by the lowest 1000-grain weight.

Table 2. Effect of varieties on grain yield and yield components regardless of sowing dates

\begin{tabular}{lrrrrrrrr}
\hline \multirow{2}{*}{ Varieties } & \multicolumn{2}{c}{ Tillers $/ \mathrm{m}^{2}$} & \multicolumn{3}{c}{ Grains/panicle, $\mathrm{n}$} & 1000 -grain wt, $\mathrm{g}$ & \multicolumn{1}{c}{ Grain yield, $\mathrm{kg} / \mathrm{ha}$} \\
\cline { 2 - 10 } & $1998 / 99$ & $1999 / 00$ & $1998 / 99$ & $1999 / 00$ & $1998 / 99$ & $1999 / 00$ & $1998 / 99$ & $1999 / 00$ \\
\hline Chaite 2 & 172 & 259 & 106 & 91 & 20.6 & 24.0 & 3366 & 4197 \\
Radha 4 & 197 & 245 & 86 & 80 & 24.8 & 27.8 & 3757 & 3769 \\
Chaite 6 & 213 & 302 & 78 & 72 & 20.9 & 22.8 & 3154 & 3777 \\
Radha 11 & 180 & 245 & 97 & 87 & 19.6 & 21.1 & 2953 & 3447 \\
\hline CV, \% & 15.4 & 14.3 & 20 & 14.5 & 4.6 & 4.5 & 17.2 & 17 \\
LSD (0.05) & 24.8 & 33 & 15 & 9.8 & 0.82 & 0.89 & 476 & 592 \\
\hline
\end{tabular}

\section{Interaction effect of sowing dates and varieties on grain yield}

The interaction effect of the sowing dates and varieties on grain yield was highly significant (Table 3). Radha 4 produced statistically the highest grain yield of $5039 \mathrm{~kg} /$ ha in 1998/99 whereas Chaite 2, Radha 4, Chaite 6 and Radha 11 were at par in 1999/00 seeded on June 15. The reduction in grain yield was noted in all tested varieties as seeding was delayed from June 15 onwards. But the reduction in the grain yield was comparatively minimum on second and third date of seeding than that of other dates. Chaite 2 gave fairly a good yield amongst the tested varieties in all seeding dates in both the years.

Table 3. Interaction effect of sowing dates and varieties

\begin{tabular}{lrrrrrrrr}
\hline \multirow{2}{*}{ Sowing date } & \multicolumn{3}{c}{ Yield, kg/ha (1998/99) } & \multicolumn{3}{c}{ Yield, kg/ha (1999/00) } \\
\cline { 2 - 5 } & Chaite 2 & Radha 4 & Chaite 6 & Radha 11 & Chaite 2 & Radha 4 & Chaite 6 & Radha 11 \\
\hline 15 June & 4472 & 5039 & 4398 & 3521 & 4140 & 4681 & 4847 & 4319 \\
29 June & 3571 & 4045 & 3516 & 3845 & 4935 & 4035 & 4129 & 4028 \\
15 July & 3177 & 3868 & 2456 & 2388 & 4754 & 3978 & 4133 & 3720 \\
29 July & 2243 & 2068 & 2248 & 2058 & 2960 & 2383 & 2001 & 1720 \\
\hline CV, \% & 17.2 & & & & & & & \\
\hline LSD (0.05) & 945 (Two varieties at the same date) & & \multicolumn{3}{c}{1160 (Two varieties at the same date) } \\
\hline
\end{tabular}

Early wet seeding (June 15) had a considerable effect on grain yield. In case if time is not permitted to sow earlier, seeding could be done up to July 14. Radha 4 was found the best variety for wet seeding condition if sown earlier. Chaite 2 performed better under delayed conditions as compared to other varieties.

\section{REFERENCES}

Adhikari NP and SP Khatiwada. 1996/97. Rice co-coordinator's report. In: Proceedings of $20^{\text {th }}$ National Summer Crops Workshop. Rice Research Reports. National Rice Research Program, Nepal Agriculture Research Council, Baninia. Dhanusha. 
Bhurer KP, SK Rijal and DN Chaudhary. 1990. Influence of date of seeding and age of seedlings on grain yield of rice under rainfed conditions. In: The Fourth Summer Crops Workshop and Research Program. National Agriculture Research Center, Ministry of Agriculture. Pp. 117-121.

IRRI. 1993. Predicted effect of climate change on rice: Production in South East Asia. In: Program Report For 1993. International Rice Research Institute, Los Banos, Manila, Philippines. P. 37.

Koirala GP. 1983. Effect of seeding dates on performances of improved rice varieties. Paper presented in $11^{\text {th }}$ Summer Crops Workshop held during 30 Jan to 1 Feb, 1983 at NRIP, Parwanipur.

Kunwar MN and GL Shrestha. 1979. Studies on date of seeding, nitrogen levels and varietal responses on rice under Parwanipur conditions. Paper presented in $6^{\text {th }}$ Summer Crops Seminar held in Department of Agriculture, Hariharbhavan, Lalitpur, Nepal.

MSTATC. 1986. A microcomputers program for the design, management and analysis of agronomic research experiments. East Lansing, Michigan State University, USA.

Pandey S and L Velasco. 1999. Economics of direct seeded rice in Asia: Patterns of adoption and research priorities. International Rice Research Notes 24(2):6-11. 